\title{
In Memoriam: Dr. Almeida Gonçalves \\ (1929-2011)
}

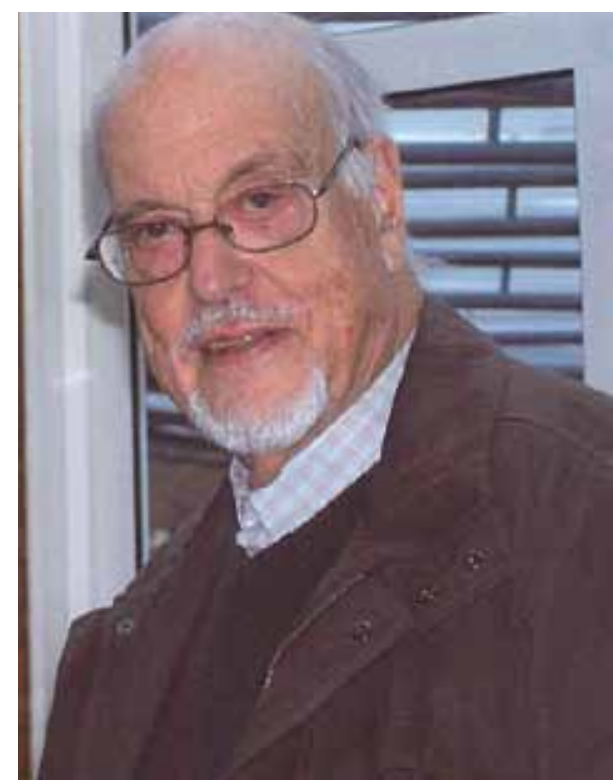

O Dr. José Carlos d'Almeida Gonçalves nasceu em 1929 no Vale de Santarém.

Especialista em Dermatovenereologia em 1961 trabalhou no IPO de Lisboa durante 25 anos. Foi primeiro Assistente do Instituto de Assistência aos Leprosos em Lisboa durante 15 anos.

Em 1964 iniciou a Carreira nos Hospitais Civis de Lisboa e em todos os Concursos de Dermatologia foi classificado em primeiro lugar.

O IPO recebia então doentes com tumores de grande parte do país, e pretendendo ter alguma autonomia terapêutica face aos métodos cirúrgicos clássicos que dominavam o Instituto, iniciou a partir de 1974 o estudo da Criocirurgia, técnica que desenvolveu, sendo considerado uma autoridade mundial no tratamento de carcinomas avançados externos (pele, mama e vulva) por este método. Foi presidente da "International Society of Criosurgery" de 1988 a 2001 e Membro Honorário até à sua morte.

Ainda no IPO criou uma variante da Quimiocirurgia de Mohs, que denominou "Quimiocirurgia Simplificada".

Progressivamente foi aumentando a assistência a tumores malignos mais graves e invasivos, criando numerosos protocolos para cancros considerados cirurgicamente inoperáveis.

Desgostoso com a falta de apoio institucional decidiu abandonar o IPO e abrir novo Serviço de Dermatologia no Hospital de Santarém em 1986, onde continuou os trabalhos de investigação e fez escola no método de criocirurgia, que possibilita aos médicos do Serviço um à vontade nesta técnica que não existe em nenhuma outra instituição do País.

Iniciou ainda no IPO estudo da subespecialidade patologia vulvar continuada no Hospital de Santarém, onde criou uma consulta desta competência em 1986, em conjunto com a Ginecologia.

Tem numerosos artigos publicados, cerca de 40, quase todos em inglês, sendo citado em artigos e livros estrangeiros, sobretudo norte americanos e argentinos. Escreveu dois capítulos para um livro sobre oncologia cutânea editado em Viena, Áustria, em 2001 e fez numerosas conferências em vários países da América Latina, onde o seu trabalho é muito conhecido e apreciado.

Criou a técnica "Criocirurgia Fraccionada", enquanto médico do Hospital de Santarém, artigo publicado em 2009 em revista americana, foi considerado um dos melhores na área na Criocirurgia.

Jubilado aos 70 anos, foi consultor do Hospital em tempo parcial, durante sete anos, até a doença forçar a sua interrupção. 


\section{In Memoriam}

Por ter um filho autista e por não haver na ocasião qualquer conhecimento desta doença em Portugal, foi forçado a estudar para conhecer o seu diagnóstico. Na ausência de assistência para estes doentes, criou a "Associação Portuguesa para Protecção das Crianças Autistas" em 1971, bem como a primeira escola especializada no seu tratamento; quer uma quer outra foram as primeiras da Península lbérica.

Desde a adolescência que se interessou pela cultura; estudou piano e depois composição com Joly Braga Santos e teve contacto com Luís de Freitas Branco.

Além da música, tão importante na sua vida, era profundo amante de literatura e artes plásticas. Recentemente colaborou com a sua mulher na organização do "Estúdio Sérgio Eloy", no Vale de Santarém, onde parte da obra deste artista está em exposição permanente. Sérgio Eloy, seu enteado, foi dos primeiros fotógrafos portugueses a criar fotografia abstracta.

Sempre aberto a novas técnicas e terapêuticas, tinha também uma permanente atitude didáctica para com todos os colaboradores médicos, enfermeiros ou outros.

Pessoalmente foi um grande exemplo de dedicação aos doentes e de trabalho árduo. Devo-lhe muitos ensinamentos em áreas da cultura além da médica, mas sobretudo tenho saudades do seu cáustico sentido de humor (nem sempre apreciado) e do quanto nos divertíamos quando trabalhávamos em conjunto.

Dr. ํㅗㅁ Mão José Marques

Directora do Serviço de Dermatologia do

Hospital Distrital de Santarém 